\title{
Inger Olsbu
}

Department of Teacher Education and School Research, University of Oslo

\section{The future of literary texts in the L3 classroom}

\begin{abstract}
Will the $\mathrm{L} 3^{1}$ classroom of the future include literature in some form? Or to put this in normative terms: For what reasons should there, or should there not, be literary texts in the L3 classroom? The present article investigates the use of literature in foreign language teaching and learning, and provides a kind of "thick description" that comes from mapping the question within a broader context. I start with the main didactic and epistemic perspectives on the use of literary texts within the field of foreign languages (FL) itself. As I will show, the diverse approaches to the use of literary texts in the language classroom rest on different views on the nature of both literary texts and language learning. This is in part because they are nurtured by different theories and academic fields (theories of language, literature and learning). As a consequence they also vary in their understanding of foreign languages as a discipline. These perspectives from within will be amplified by introducing what I have termed two competing discourses of literature and education ("literature as suppressive" and "literature as suppressed"), and by showing how they can be related to FL teaching and learning. These are in turn framed within the macro perspective of educational philosophies and the functions of school in society. Finally, I will consider the specific Norwegian case, with a particular focus on the L3 subject curriculum $^{2}$ of the last reform (henceforth LKO6) ${ }^{3}$, and its consequences for the use of literary texts.
\end{abstract}

\section{Introduction}

As Paran (2008) has commented, both supporters and opponents of the use of literature in FL education concur that there is little research in this area. Although agreed to be under-investigated, a considerable corpus of studies has still emerged over the years (see Carter, 2007; IFS ${ }^{4}$; Liskin-Gasparro, 1999; Paran, 2008; and TodoELE.net ${ }^{5}$ ). In the Norwegian context there are numerous works on the use of literary texts in the L2 (e.g. Fenner, 2001; Hestnes, 2012; Ibsen \& Wiland, 2000; Olsen Eikrem, 1999; Wiland, 2007). Ibsen and Wiland (2000) offer the most thorough analysis of the role of literature in English 
teaching and learning, including both a historical review of Norwegian school reforms, curricula and exams, as well as methodological perspectives and discussions. When it comes to the use of literary texts in the L3 classroom, the most complete treatment is offered by Nesje Vestli (2010). (See also Bruland, Langemeyer \& Lindemann, 1994; Gundersen, Henriksen \& Reinton, 1986; Olsbu \& Salkjelsvik, 2008.).

In the following, I will outline the main didactic and epistemic perspectives on the use of literary texts in the FL classroom. Classifying the vast diversity of approaches into a few categories implies, however, a danger of simplification. Especially so in a field that has developed over time, and where one finds somewhat different traditions related to different target-language areas. Still, I consider it necessary in order to provide a clear overview of how the different approaches connect with particular understandings of literature, language learning and FL disciplinary identity.

Perspectives from within: the main didactic and epistemic perspectives on the use of literary texts in the foreign language classroom

Bredella (2004a) offers a fine review of some of the most important "justifications" for using literature in the FL classroom. I have taken these as a point of departure for the first four categories to be presented in this article: 1) the task-based approach, 2) the stylistic approach, 3) the experiential approach, and 4) the intercultural approach. In addition I will include a seemingly outdated perspective: 5) the canonical approach, arguing that this view is still present in FL text-books and in certain educational settings. The last category: 6) the noliterature approach, covers the didactic and epistemic perspectives of those who reject a role for literature in the FL classroom. It should be stressed, though, that these categories do not always appear in a "pure" or exclusive form, but are frequently combined. They are, therefore, best understood as prototypical.

\section{The task-based approach}

The task-based approach looks upon literature as a resource for language teaching and learning, and - when selected and used in an appropriate way - a source of motivation. In this approach, the literary text is seen primarily as a point of departure for a variety of activities, stimulating not only the traditional receptive skill of reading, but also productive activities such as creative writing or role-play. According to this view, literature provides an opportunity for the learner to work on all the main language skills (listening, speaking, reading, writing and spontaneous communication). The literary text should "be taken down from the pedestal” (cfr. Nesje Vestli, 2008, p. 34) and used pragmatically 
in the FL classroom, allowing it to be cut up, manipulated or experimented with in other ways. As a consequence, the concept of literature that underpins this approach is rather open and pragmatic, and the question of literary value is not of vital importance ${ }^{6}$. Indeed, Duff \& Maley (1990) explicitly reject literary quality as sole criterion for text-selection, claiming that "quite often 'bad writing' proves more useful or stimulating than 'good'” (p. 6). Since the didactic value of literary texts resides in the interesting topics they offer, and the tasks one can generate from them, this is also what guides text- selection.

The theoretical foundations of the task-based approach are found in communicative and task-based language teaching, in holistic and action-oriented learning and teaching, and in production and action oriented didactics of literature (for these last perspectives, see Finkbeiner, 2004, pp. 255-258 and Nesje Vestli, 2008, pp. 19-21). The task-based approach has been quite central to the endurance of literary texts in the FL classroom (Bredella 2004a, p. 376). Some well-known contributors are Duff \& Maley (1990), Carter \& Long (1991), Lazar (1993) and Collie \& Porter Ladousse (1996). This approach to literature in the FL classroom is, moreover, well represented in different target language traditions (e.g. Koppensteiner [2001] from the German context and Mendoza Fillola [2007] from the Spanish context).

I would argue that the strength of the task-based approach lies in its applicability on all language levels, and in its focus on active learners and creative language-production. Both aspects are particularly significant in a field where literature traditionally has been reserved for advanced language levels and where the focus often has been on receptive skills (reading) or literary analysis. Still, if not supplied by other approaches, it can lead to a certain neglect of both the content of the literary text and the learner's reception of it. In fact, the taskbased approach may result in a kind of "springboard-didactics" (see O'Sullivan \& Rösler, 2013, pp.126-127) that uses the literary text as a "pretext" to introduce cultural themes or as mere language material for linguistic activities. This approach is, therefore, well suited to familiarize learners with the use of literary texts on introductory levels, but should thereafter be combined with approaches that give more attention to the process of reading and interpreting literary texts.

\section{The stylistic approach}

Wales (2011) states that the goal of most stylistic studies is "to show how a text 'works'”. This surpasses the simple description of linguistic features as it also involves the explanation of "their functional significance for the interpretation of the text” (p. 400). By studying literature, the learners become aware of how subtle nuances of meaning are created. This insight is held to motivate further reading and appreciation of literary texts. 
The works of Widdowson $(1975,1992)$ are classics within the stylistic approach. To Widdowson (1992), the pedagogical value of his practical stylistics resides in how it provides learners "with ways of justifying their own judgment by making as precise reference to the text as possible" (p. xii). Perspectives from stylistics can be found in Brumfit and Carter (1986), Short (1988), Simpson (1997), Parkinson and Reid Thomas (2000), Scott and Tucker (2001), and Watson and Zyngier (2007).

According to the stylistic approach, the main purpose of studying literary texts is to gain insight into language use. Literary discourse is considered to be typified by a particular "linguistic resourcefulness" (Simpson, 1997, p. 2), and this is why advocates of stylistics look upon the literary text as particularly valuable for the FL classroom. ${ }^{7}$ Moreover, stylistics is seen as an alternative to expert analysis of literature, enabling the learners to find their own way into literary texts (Widdowson, 1992; Simpson, 1997). By combining the fostering of linguistic and literary competence, stylistics has been proposed as a way to bridge the gap between language and literature classes at college/university level (Parkinson \& Reid Thomas, 2000; Scott \& Tucker, 2001), where these often appear as separate and autonomous subjects.

I agree with the authors who see stylistics as a means to integrate language and literature studies, and I also believe that stylistics may have an empowering effect on new students of FL literature. At an introductory level, I still think that the stylistic approach - at least in a "pure" version - would prove too specialized and too language-oriented, requiring not only a certain level of FL skills, but also of linguistic competence in general. Moreover, the dissociation from context in certain versions of stylistics represents a risk of forgetting the social and political nature of literary texts. In the stylistic approach, what is clearly most important is the linguistic dimension of literature and FL learning. As a consequence, other dimensions like the cultural, personal or affective ones are in danger of being left behind.

\section{The experiential approach}

In the experiential approach, the emphasis is on the encounter between the literary text and the reader. A central idea is that we experience the world and human relations from new perspectives through literature. The didactic motivation for the experiential approach is grounded in the idea that literature is especially suited for the fostering of humanist values such as empathy and democracy (see also cognitive theories of literature and Theory of Mind [ToM] on this point, e.g. Comer Kidd \& Castano, 2013).The experiential approach is therefore close to perspectives on FL teaching and learning which emphasizes general educational goals or Bildung in addition to more practical language skills. The didactic value of the literary texts lies in their ability to involve the 
learners affectively and challenge their established views (two vital factors for Bildung-processes to take place, see Aase, 2005, p. 17). Moreover, the literary encounter, in comparison to a lived experience, offers the reader a certain distance for reflection.

Among the theoretical foundations, we find reader-response theory in the tradition of Iser, Dewey's aesthetics, Rosenblatt's distinction between aesthetic and efferent reading, and Bruner's theory of a narrative mode of thought (see Bredella, 2004a). The view that the literary text is more "open" and multilayered than other texts is part of the epistemic basis of the experiential approach, as is also the idea that the literary text acquires its signification through the reading process. Iser (1980) holds that the meaning of literary texts is not to be found objectively in the texts, or in the subjective view of the reader, but in the interaction between the two. For Dewey it is through the experience of the reader, through his or her recreation of the literary text, that it turns into a work of art (2008 [1934], p. 211). Rosenblatt, argues that the literary text favors an aesthetic way of reading that focuses on the reading experience in itself. This stands in contrast to non-aesthetic, efferent reading that focuses "on what will remain after the reading - the information to be acquired, the logical solution to a problem, the actions to be carried out” (1994 [1978], p. 23). According to Bruner (1986), literature belongs to a narrative mode of thought which is subjective, pluri-significative, guided by logic of intention and of the "subjunctive" (what is possible to imagine). ${ }^{8}$ Implicit in the experiential approach is an idea of literary value connected to the attributes described above. In Norway, Ibsen and Wiland (2000), Fenner (2001), and Wiland (2007) adhere to the experiential approach, insofar as they focus on the interaction between text and reader and the personal responses and reflections that stem from that encounter.

In the experiential approach the value of the literary text resides in its meaningfulness, and reading literature is seen as an activity that involves the whole person (feelings, attitudes, reflections). I find the focus on aesthetic reading especially important, as this perspective tends to get lost in the reading strategies currently promoted in FL teaching and learning. The experiential approach represents a holistic view of language learning that includes a dimension of personal growth and Bildung. Still, I would argue that such general educational goals need to be "translated" into concrete activities and learning outcomes in the FL classroom for not to remain lofty ideals. Another question is how to make this approach work for learners of different ages and with variable competence in the FL. If literary reading is to result in a meaningful and motivating encounter (and not in a demotivating experience of impotence), the literary texts need to be carefully selected (in terms of linguistic, cultural and cognitive complexity) to match the profile of the readers. 


\section{The intercultural approach: Literature as intercultural encounter}

The intercultural approach to the use of literature in the FL classroom is of growing importance within the field of foreign languages. This approach shares many of the theoretical foundations of the experiential approach, such as the focus on the interaction between reader and text, but is also nurtured by intercultural theory, postcolonial theory and cultural studies. A major didactic and epistemic reason for the use of literary texts in the intercultural approach (as in the experiential), is the belief that literature enables us to see the world from a perspective different from our own. Moreover, Bredella, (2004b) underlines the special value of "postcolonial and minority literature" as it "often depicts intercultural encounters" (p. 382). An issue of debate within this approach is just how to understand the concept of intercultural. In the tradition of Byram (1997), intercultural competence has been broadly defined as "the ability to interact effectively with people from cultures that we recognize as being different from our own” (Guilherme, 2004, p. 297). Kramsch (2011) has criticized this approach for being based on a view that understands culture in terms of a noun with an article; $a$ culture/the culture, and, quite often, territorial borders. She argues instead for a late-modernist view of culture, associated with heterogeneous and fluid cultural relations, "more akin to literary interpretation than to the memorizing of facts" (p. 235). A common metaphor for the intercultural encounter, the literary encounter and the encounter with a new language, is the evocation of a "third place" (Bhabha, 1994; Gonçalves Matos; 2012, Kramsch, 1993), that is, an "in-between space" where new understandings of self and other can take place. Among the foreign language professionals who have contributed to the field of literature and intercultural communication are Bredella (1996, 2000, 2004), Delanoy (1993), Kramsch (1993, 2003, 2011), and Gonçalves Matos (2012). ${ }^{9}$

In the intercultural approach the literary text is primarily seen as a cultural product which expresses intercultural relations and conflicts through choice of topics and discourse. As it involves our prior experiences, beliefs, values etc., the literary encounter has a potential for learning that goes beyond the reception of an informative text of cultural "facts". In a real intercultural encounter there is something at stake, as it "stretches the cultural identities involved" (Guilherme, 2004, p. 297).

I share the view that literary texts represent a resource that is especially suited for teaching intercultural understanding in the FL classroom. As culture is intrinsically part of these texts (not only through topics, settings and characters, but also through language use), they offer a richer material than informative texts about cultural "facts". Furthermore, the literary encounter might parallel a real intercultural encounter, but without the stress a real world situation involves. I would argue, though (like Kramsch, 2011), that it is time to adopt a late-modernist view of culture that inserts FL teaching and learning in the 
contemporary globalized world of cultural and linguistic heterogeneity and multiple identities. In the FL classroom of the 21th century the idea of a homogeneous target culture and language should be left behind, as should also the ideal of the native speaker.

\section{The canonical approach}

Traditionally, the literary text in the FL classroom was associated with cultura in a dual sense; as cultivation and as canon. The reading and translation of literary texts in the FL classroom aimed to cultivate qualities such as analytical skills and logical thinking. At the same time, literature was associated with cultura in the sense of exceptional, cultural achievements: "the best that has been thought and said" in Arnold's tradition. These two meanings of culture were then intertwined (Risager, 2003; Williams, 1983), and the approach to literature as cultivation through emblematic texts became part of the heritage that the modern foreign languages brought with them from the classical studies of Latin and Greek (Trebbi, 2005). In the beginning of the $20^{\text {th }}$ century in Norway, Shakespeare was read in the English classroom (Ibsen, 2000, p. 21), and Goethe and Schiller in the German classroom (Vaagland, 1991, p. 38). The approach to literature as "big C" Culture has been closely related to the idea of nationhood. It was the major national contributions to universal cultural heritage (in practice the western canon) that were to be included in the curricula. Today, after decades of canon-critique and the introduction of a pragmatic concept of culture $^{10}$ in FL teaching, this approach might appear irrelevant. Still, literature in the form of emblematic texts never completely disappeared from the FL classroom. As Mitchell (2011) comments, this approach "maintains a foothold (...) in academic high schools in parts of continental Europe where the study of pre- $20^{\text {th }}$ century foreign language literature (...) is still prized” (p. 87). Also in the textbooks, the references to the literary masterpieces of the target language countries seem to have survived. A study of textbooks in Spanish for lower secondary school in Norway (Olsbu, in progress) shows, for instance, that most of them include some information about Cervantes and an extract of Don Quijote.

I suggest that the canonical approach to literature should be left behind in a modern FL classroom. Still, I don't reject the idea that canonical works and authors can have a role to play in FL teaching and learning. Being able to situate Cervantes and Don Quijote as cultural references is relevant for any user of the Spanish language. Canonical literature represents, moreover, a significant historical "archive" of culturally influential texts, and is, as such, relevant for the more specialized FL literature classes at college/university level. This view of literature as "archive" implies however, that texts - whether canonical or 
marginalized - are considered in the context of their cultural and historical existence.

\section{The no-literature approach}

Within the field of FL teaching and learning, there are also voices opposing the use of literary texts in the FL-classroom. Horowitz rejects the association between "educative" goals (empathy, critical thinking etc.) and literature, and argues against the idea that a literary text "provides richer opportunities for interpretation" than other text genres (1990, p. 163). Edmondson (1997) claims that the literary text possesses no essential characteristics (compared to other texts), that makes it particularly suitable for successful FL acquisition. Even though I find Edmondson's questioning of the nature of literary texts an important issue (see also Bredella, 1996, on this point), I disagree with the basic premise of his argumentation, i.e. that the sole and final purpose of language learning is successful language mastery. This is why Edmondson harshly criticizes what he sees as a long and negative tradition of different kinds of "external rationale" for language learning. To Edmondson, the "literary one" has been the most persistent of such external justifications: “...we seem to insist on crying, ‘it's not just language we're teaching you know!'”(p. 53). I would argue that Edmondson's view of FL teaching and learning is reductive. Paran (2006) characterizes this position as an "isolationist" one (p. 8).

Resuming internal perspectives: different views on literature, language learning and the disciplinary identity of foreign languages.

As stated initially, the diverse approaches to the use of literary texts in the FL classroom rest on different views on the nature of both literary texts and language learning. Still, all the pro-literature approaches coincide in that the literary text has some particular characteristics - be it "openness", "linguistic resourcefulness", "creative use of language" etc. - that justify its role in the FL classroom. However, this view does not find much resonance in the current educational guidelines. In the L3 subject curriculum of LK06 literature has been absorbed by the vast category of "authentic texts in different genres", leaving little room for the literary text's distinctiveness and particular contribution to FL teaching and learning. In the Common European Framework of Reference for Languages (henceforth CERF), the literary text has become part of the likewise broad category of aesthetic use of language. Such a wide classification not only leads to ambiguity as regards text-levels (aesthetic use of language can be found within text-genres that are nor predominantly "aesthetic"), but it also leaves out 
of sight the differences between a nursery rhyme and Don Quijote, or between a text-book story and an authentic literary text.

I would argue that this problem of differentiation is also present in the taskbased approach as it rests on a similar broad concept of literature. Much more specific about the attributes that makes literature valuable to FL teaching and learning are the experiential and the intercultural approaches that consider the literary texts to be more "open", multilayered, affectively engaging, and culturally complex than other kinds of texts. But again we face a problem of definition: are these characteristics present in all literary texts, or just in some? The experiments of Comer Kidd and Castano (2013) illustrate this problem. Their main hypothesis is precisely that not all kinds of literature foster the capacity to understand others (ToM), but that it is mainly "literary fiction" (as opposed to "popular fiction") that has the necessary attributes for such a purpose $^{11}$.

It is today widely accepted that literature cannot be defined by necessary and sufficient criteria. Eagleton (2012) proposes instead that literature should be considered a prototypical category whose members share a kind of family resemblance. ${ }^{12}$ Understood this way, the members of the category of literature are quite heterogeneous, and not all "literary texts" are therefore suitable for the same purposes within FL teaching and learning. As a consequence, the initial question of whether or not there should be literary texts in the future L3 classroom has to be more specific: what kind of literary texts should be used in the L3 classroom for what reasons?

The six approaches to literature described in this article also emphasize different elements as central to the study of foreign languages, hence promoting different images of FL disciplinary identity. Whereas the task-based approach highlights communicative, task-based and multi-skill oriented FL teaching and learning, the linguistic dimension of the FL is at the core of the stylistic approach. The intercultural approach focuses on culture and cultural relations, and the experiential approach promotes an image of FL as a holistic discipline aimed at personal development. The canonical approach considers cultural heritage to be central to FL teaching and learning, while the no-literature approach consider language mastery to be the exclusive purpose of studying FL. In other words, each of these approaches takes the FL disciplinary identity in a different direction. This shows that defending the use of literature in the FL classroom does not necessarily imply a common view of what FL teaching and learning should be all about. Still, it neither means that the different approaches are incompatible. A decisive point when it comes to all FL teaching and learning is the fact that we are not talking about a homogeneous group of learners, ages, language levels, cultural and linguistic contexts etc. The different approaches might fill important functions in certain contexts, but prove unfortunate in others. Some of them would for instance need quite a lot of adaptation to be successful in introductory FL courses. This does not imply, however, that 
authentic literary texts are in themselves unsuitable for beginners. As Hunfeld (1990) has shown, authentic literary texts do not have to be more linguistically "difficult" than the texts specially composed for use in FL teaching and learning. What they can offer additionally is a more intellectually and culturally challenging material.

Expanding the context: two central discourses of the relationship between literature and education.

If we now leave the FL field-specific discourses of literature, and expand the context to education in general, we can address two discourses of literature that have had a particular impact. I use the term discourse in the sense of a particular discourse that gives meaning to experiences from a certain perspective (see Fairclough's concept of discourse in Winther Jørgensen \& Phillips, 2011, p. 79). To simplify, I will call these two discourses "literature as suppressive" and "literature as suppressed". Both discourses can be related not only to the use of literary texts in the FL classroom, but also to the discussion of the identity of the FL as a discipline, and to the more general debate about the functions of school in society.

\section{Literature as suppressive}

At the core of the literature as suppressive- discourse is the idea that education reproduces the power relations found in society, and that art and literature are part of this. According to Bourdieu and Passeron (2006 [1979]), the educational system reproduces class differences through the favoring of certain kinds of knowledge and cultural values. That is, some kinds of habitus and cultural capital are rewarded by the educational field while others are not, thereby producing mechanisms of inclusion and exclusion. In relation to literature, Bourdieu breaks with the Kantian aesthetics of disinterestedness, and shows how even art and cultural taste are related to a specific kind of cultural capital, social class and power (Bourdieu 1995 [1979], 1993, see also Speller, 2011). Literature becomes suppressive when the educational assessment of it depends on a pre-established cultural capital unequally distributed among social classes.

Historically, the literature as suppressive -discourse was nurtured by the anti-authoritarian and anti-elitist currents of the 1960s, with the studentrebellions and the subsequent revisions of teaching methods and curricula, and most importantly- the critiques of the literary canon(s) that sprung out of those experiences. For the foreign languages, this implied a break with the old tradition of teaching big C Culture. In general this was an emancipatory discourse that led to the gradual integration of more women and minority 
authors, as well as children's and young adult literature in the curricula of schools and universities. But in the specific case of foreign languages, and especially the L3 at the lower educational levels, it seemed as if the literary texts had been so strongly associated with a pre- $20^{\text {th }}$ century, elitist approach to FL education that they tended to disappear from the curricula instead.

Indeed, during the 1970s there is an international trend of relegating literary texts to "a marginal role" in the teaching and learning of foreign languages (Paran 2006, p.1). This marginalization can be related to several factors, among them the cultural and educational transformations described above, but also the ongoing process of globalization and the increasing demand for FL competence. It all led to a claim for "opening up" the foreign languages, traditionally seen as both theoretical and difficult subjects (Trebbi, 2005), and for making them more accessible and "practical" - both as a democratic project, but also due to the need for broad language competence in a globalized world. But in the efforts to democratize the FL classroom, literature seemed to be considered an obstacle, a remnant from the theoretical orientation of the past and antagonistic to modern, communicative FL teaching and learning.

\section{Literature as suppressed}

If we look at the second discourse -literature as suppressed- its main message is that traditional humanist and aesthetic subjects such as art, music and literature are being sacrificed due to a neoliberal paradigm that focuses exclusively on economic utility. A central project in critical discourse analysis (see Fairclough, 2010) has been to show how the discourse of the market is invading all areas of society, including public education. According to Paran (2006, p. 8), Edmondson's (1997) perspective on FL teaching and learning is shaped by this market discourse.

The historical roots of the literature as suppressed-discourse are to be found in the 1980s, with the new Right and the introduction of New Public Management which initiated a "school as enterprise" approach to education (Imsen, 2010 [1997], p. 202). The focus on utility is related to a macroperspective that links national economic growth to education (human capital theory). Most of the time, this is translated into a demand for more competence in mathematics, natural sciences and technology, whereas the humanities and the arts are considered "soft knowledge" of little national importance (see Imsen, 2010, p. 265). Martha Nussbaum (2010) speaks of a "silent crisis":

The humanities and the arts are being cut away, in both primary/secondary and college/university education, in virtually every nation of the world. Seen by policymakers as useless frills, at a time when nations must cut away all useless things in order to stay competitive in the global market, they are rapidly losing their place in the curricula, and also in the minds and hearts of parents and children. (2) 
Nussbaum criticizes what she considers a too dominant "profit Motive" in education, and makes the case for the arts and humanities in what she terms "an education for a more inclusive citizenship" (2010, p. 7). According to Tornberg (2013), a similar tension as the one described by Nussbaum, has been present in the history of the foreign languages in postwar Europe. On one hand, FL teaching and learning has been considered part of a democratic, antiauthoritarian peace-project, focusing on intercultural understanding and personal growth. On the other hand, FL studies have been seen as part of the development of the EU inner market with its need for free flow of manpower and therefore requiring classifiable, measurable and comparable language skills.

Literature and education on a macro-level: functions of school in society

In the discourses of literature in education described above, and also in the different approaches to literature within the field of FL teaching and learning, there is an implicit value judgment of what functions of school in society should be given priority. Clark (1987) argues that foreign language educational policy should be understood in relation to three major educational philosophies namely classical humanism, reconstructionism and progressivism (Clark, 1987, pp. 91-99). Broadly speaking, the first philosophy focuses on education as reproduction of cultural heritage, the second on society's changing needs for knowledge and competence, and the third on how education contributes to personal development and the shaping of identities. Within this frame, the discourse of literature as suppressive can be seen as a reaction to classical humanism in an elitist version, whereas the discourse of literature as suppressed can be seen as a reaction to a reconstructionism primarily concerned with the socio-economic dimension of education.

In a very general approach to functions of school in society, Mitchell (2011), describes classical humanism as internationally prominent until World War II, but then gradually left behind for a "reconstructionist rationale" focusing on economic compatibility and the challenges of globalization. Mitchell links reconstructionism to a focus on learning outcomes and "an instrumentalist focus on the achievement of defined skills and proficiency levels" (Mitchell 2011, pp. 88 -89). However, the three educational philosophies have always coexisted in practice, but with varying degrees of influence. In fact the different approaches are often combined with and modified by each other.

In the Norwegian educational reforms of L97 and R94 we find considerable influence from classical humanism. Aasen (2007, p. 35) speaks of a "cultural conservative knowledge regime", reflected, among other aspects, in the extensive inclusion of suggested literary readings in the L3 subject curriculum. 
However, as I will show, the LK06 curriculum represents a more reconstructionist approach to FL teaching and learning.

\section{The case of Norway}

One of the most significant changes in the LK06 as compared to its predecessors, L97 and R94, is the new rhetoric of competences and skills, echoing the CERF. The focus has clearly shifted from the content and methodology of the L3 to an insistence on concrete learning-outcomes: from a "governing through input" to a "governing through output", as Aasen (2007, p.38) puts it. (This is what Mitchell [2011] relates to reconstructionism and Aasen to a "market-liberal knowledge regime" [2007, pp. 37-39]). LK06 combines freedom of methods and content with quite rigidly defined learningoutcomes, which in the case of the L3 subject means testable language skills. Moreover, the literary text has disappeared as an independent category from the L3 subject curriculum and has been assimilated by the much broader category of "authentic texts". The insistence on the L3 as a "practical subject", which according to Heimark (2007), typically has been interpreted in terms of privileging oral language use, further complicates the case for literature. All in all, these characteristics of the LK06 offer poor conditions for the use of literary texts in the L3 classroom.

Still, the general goals of the L3 subject curriculum, with its humanistic discourse of "intercultural competence", "insight into the way others live and their views" "personal growth" and "democratic commitment" (Ministry of Education and Research, 2006, p. 2), echo many of the central aspects of the experiential and intercultural approaches to literature in the FL classroom. Nesje Vestli (2008) even comments that these goals are "like a paraphrase over the attributes of literature" (p. 7). Moreover, in the general part of the educational guidelines (The Core Curriculum, inherited from the prior reform), we find arguments that resemble those of the canonical approach to literature, as it states the ambition to "provide powerful exposure to the greatest achievements in literature and art" (Ministry of Education and Research[1993], 2005, p. 40).

I would argue that there is a tension in LK06 between general humanistic goals, on the one hand, and subject-specific and testable skills, on the other. As long as the former suffer from a lack of concretization, and the latter continue to gain strength, I believe there will be little space for literature in the L3 classroom. This is because the use of literary texts is not so easily translated into testable skills or “can do”-statements. As O'Sullivan and Rösler (2013, p. 16), point out, many of the educative goals associated with literature, such as for instance intercultural understanding or empathy, are difficult to test.

Olsbu and Salkjelsvik (2008), have argued that the discourse of competences is a challenge to the use of literary texts in the L3 classroom, since there is no 
mention of a specific literary competence, in neither the CERF, nor in the Norwegian L3 subject curriculum, and, since literature is neither mentioned explicitly in relation to other competences (e.g. cultural or linguistic competence) nor skills (e.g. reading). Fleming (2007) has also discussed the limitations and possibilities of competence frameworks in relation to literature. He suggests that formulating competence statements for the use of literature would be a useful starting point for a discussion of the place and purpose of the literary text in the FL classroom. Bredella and Hallet (2007), are likewise concerned about how the competence-approach affects the use of literary texts in FL teaching and learning. To these authors the concept of competence currently applied in FL is too narrow and too concerned with testability, and they suggest that it should be expanded and merged with the concept of Bildung. The key to such a reconceptualization is literature. Defining the competences potentially stimulated through the use of literature could, according to Bredella and Hallet, contribute to overcome the current antagonism between objective, testable skills, on one hand, and more general educational goals, on the other (cfr. the tension described in LK06). I contend that these efforts to integrate literature in the competence and skills approach are of vital importance to the future of the literary texts in the L3 classroom.

\section{Will there be literature in the L3 classroom of the future?}

In this article I have addressed some of the aspects I believe will have an influence on the future of the literary text in the L3 classroom, including both a micro- and a macro-perspective. As I have shown, the different approaches to the use of literature in FL teaching and learning represent different views on literature and language learning. I have therefore argued that the normative question of whether or not there should be literary texts in the L3 classroom is not enough. What needs to be addressed is what kind of literary texts should be used how, in what contexts, and for what reasons. As claimed in this article, each of the approaches to literature takes the FL disciplinary identity in a different direction. The future of the literary texts in the L3 classroom is therefore also a question of the future of the discipline itself. Seen from a macroperspective, a too one-dimensional focus on presumed societal needs for language knowledge and competence will most probably have a negative impact on the future presence of literary texts in the L3. This is related to the current focus on testable skills in educational guidelines, which also tends to exclude the literary texts from the classroom. But the picture is complex, there are many voices defending a view of the foreign languages as broad humanistic subjects, and the literary text as a particularly valuable resource for the FL classroom. Still, the difficulties in defining the concept of literature and the dismissal of the literary text as a specific kind of text in the L3 subject curriculum and in the 
CERF represent important challenges to the role of literature in future FL teaching and learning. Another important challenge is the negative associations from the past that link literature to an elitist, old-fashioned and "big C" Culture approach to language teaching. Finally, I would argue that the future of literary texts in the L3 classroom will depend on whether literature can be integrated into the current competence and skills approach. If this is to succeed, there is a need for a strong FL didactics of literature which actively shows how the use of literary texts can be linked to specific learning outcomes or skills. In the Norwegian L3 context, the work of Nesje Vestli (2008) deserves mention in this sense, but there is still a need for more studies and concrete teaching examples.

\section{References}

Bhabha, H. (1994). The location of culture. London: Routledge.

Bourdieu, P. \& Passeron, J.-C. (2006 [1979]). Reproduktionen. Bidrag til en teori om undervisningssystemet. København: Hans Reitzels Forlag.

Bourdieu, P. (1993). The field of cultural production. Essays on art and literature. Colombia: Colombia University Press.

Bourdieu, P. (1995 [1979]). Distinksjonen. En sosiologisk kritikk av dømmekraften. Oslo: Pax Forlag.

Bredella, L. (1996). The anthropological and pedagogical Significance of Aesthetic Reading in the Foreign Language Classroom. In L. Bredella \& W. Delanoy (Eds.), Challenges of Literary Texts in the Foreign Language Classroom (pp. 1-30). Tübingen: Gunter Narr Verlag.

Bredella, L. (2000). The Significance of Intercultural Understanding in the Foreign Language Classroom. In T. Harden \& A. Witte (Eds.), The Notion of Intercultural Understanding in the Context of German as a Foreign Language (pp. 145-166). Bern: Peter Lang.

Bredella, L. (2004a). Literary texts. In M. Byram (Ed.), Routledge Encyclopedia of Language Teaching and Learning (pp. 375-382). London and New York: Routledge.

Bredella, L. (2004b). Literary texts and intercultural understanding. In M. Byram (Ed.), Routledge Encyclopedia of Language Teaching and Learning (pp. 382-387). London and New York: Routledge.

Bredella, L \& Hallet, W. (2007). Einleitung: Literaturunterricht, Kompetenzen und Bildung. In L. Bredella \& W. Hallet (Eds.), Literaturunterricht, Kompetenzen und Bildung (pp. 111). Trier: Wissenschaftlicher Verlag Trier.

Bruland, H., Langemeyer, P. \& Lindemann, B. (Eds.) (1994). Deutschsprachige Literatur im Fremdsprachenunterricht (Trekkfugl, vol. 1). Tromsø: University of Tromsø.

Brumfit, C. \& Carter, R. (Eds.). (1986). Literature and language teaching. Oxford: Oxford University Press.

Bruner, J. (1986). Actual Minds, Possible Worlds. Cambridge, MA and London: Harvard University Press.

Byram, M. (1997). Teaching and assessing intercultural communicative competence. Clevedon: Multilingual Matters.

Carter, R. A. (2007). Literature and language teaching 1986 - 2006: A review. International Journal of Applied Linguistics 17(1), 3-13.

Carter, R. A. \& Long, M. (1991). Teaching literature. New York: Longman.

Clark, J. L. (1987). Curriculum renewal in school foreign language learning. Oxford: Oxford University Press. 
Collie, J. \& Porter Ladousse, G. (1996). Paths into Poetry. Oxford: Oxford University Press.

Comer Kidd \& Castano (2013). Reading literary fiction improves Theory of Mind. Science, 342(6156), 377-380.

Delanoy, W. (1993). “Come to Mecca” - Assessing a Literary Text's potential for intercultural learning. In W. Delanoy, J. Köberl \& H. Tschachler (Eds.), Experiencing a foreign culture (pp. 275-299). Tübingen: Günter Narr Verlag.

Dewey, J. (2008 [1934]). «Å gjøre en erfaring». In K. Bale \& A. Bø-Rygg (Eds.), Estetisk teori. En antologi (pp.196-214). Oslo: Universitetsforlaget.

Duff, A. \& Maley, A. (1990). Literature. Oxford: Oxford University Press.

Edmondson, W. (1997). The role of literature in foreign language learning and teaching: some valid assumptions and invalid arguments. AILA Review, 12, 42-55.

Fairclough, N. (2010). Critical discourse analysis and the marketization of public discourse: the universities. In N. Fairclough, Critical discourse analysis. The critical study of language (pp. 91-26). Harlow: Pearson Education Limited.

Fenner, A.-B. (2001). Dialogical interaction with literary texts in the lower secondary classroom. In A.B. Fenner (Ed.), Cultural awareness and language awareness based on dialogical interaction with texts in foreign language learning (pp.13-46). Strasbourg: ECML/Council of Europe Publishing.

Finkbeiner, C. (2004). Handlungsorientierter Unterricht (Holistic and action-oriented learning and teaching). In M. Byram (Ed.), Routledge Encyclopedia of Language Teaching and Learning (pp. 255-258). London and New York: Routledge.

Fleming, M. (2007). The use and misuse of competence statements with particular reference to the teaching of literature. In W. Martyniuk (Ed.), Towards a common European framework for language(s) of school education: proceedings from a conference (pp. 4760). Krakow: Universitas.

Gonçalves Matos, A. (2012). Literary texts and intercultural learning. Exploring new directions. Bern: Peter Lang.

Guilherme, M. (2004). Intercultural competence. In M. Byram (Ed.), Routledge Encyclopedia of Language Teaching and Learning (pp. 297-300). London and New York: Routledge.

Gundersen, K., Henriksen, T. \& Reinton, R. E. (Eds.). (1986). Litteraturens plass $i$ språkundervisningen. Hvorfor, hva, hvordan (Narcisse, vol. 6). Oslo: University of Oslo.

Heimark, G. E. (2007). Hvordan forstå 'praktisk' tilnærming i 2. fremmedspråk? Noen betraktninger fra fagdidaktikk og praksisfeltet. Språk og språkundervisning, 2, 8-16.

Hestnes H. (Ed.). (2012). Litteratur. Språkfag 5, Idéhefter for læerere. Trondheim: Akademika forlag.

Horowitz, D. (1990). Fiction and nonfiction in the ESL/EFL classroom: Does the difference make a difference? English for Specific Purposes, 9, 161-168.

Hunfeld, H. (1990). Literatur als Sprachlehre: Ansätze eienes hermeneutisch orientierten Fremdsprachenunterrichts. Berlin: Langenscheidt.

Ibsen, E. \& Wiland, S.M. (2000). Encounters with literature. Kristiansand: Høyskoleforlaget. Imsen, G. (2010 [1997]). Lererens verden. Oslo: Universitetsforlaget.

Iser, W. (1980). The act of reading. A theory of aesthetic response. Baltimore: John Hopkins University Press.

Koppensteiner, J. (2001). Literatur im DAF-Unterricht: eine Einführung in produktiv-kreative Techniken. Wien: öbv \& hpt.

Kramsch, C. (1993). Context and Culture in Language Teaching. Oxford: Oxford University Press.

Kramsch, C. (2003). From practice to theory and back again. In M. Byram \& P. Grundy (Eds.), Context and culture in language teaching and learning (pp. 4 -17). Clevedon: Multilingual matters. 
Kramsch, C. (2006). Culture in language teaching. In M. Leth Andersen, K. Lund \& K. Risager (Eds.), Culture in language learning (pp. 11-27). Aarhus: Aarhus University Press.

Kramsch, C. (2011). Cultural perspectives on language learning and teaching. In K. Knapp \& B. Seidlhofer (Eds.), Handbook of foreign language communication and learning (pp. 219-245). Berlin \& New York: Walter de Gruyter.

Lazar, G. (1993). Literature and language teaching. A guide for teachers and trainers. Cambridge: Cambridge University Press.

Liskin-Gasparro, J. (1999) Bibliography: The teaching of literature in foreign language programs. Retrieved from: http://pages.uoregon.edu/aausc/archive/prgadmin/lit-read.html

Mendoza Fillola, A. (2007). Materiales literarios en el aprendizaje de lengua extranjera. Barcelona: Horsori Editorial.

Ministry of Education and Research. ([1993]2005). Core Curriculum. Retrieved from: http://www.udir.no/Upload/larerplaner/generell_del/5/Core_Curriculum_English.pdf?epsl anguage $=$ no

Ministry of Education and Resarch. (2006). Subject curriculum for foreign languages. Retrieved from http://www.udir.no/kl06/FSP1-01/Hele/Formaal/?lplang=eng

Mitchell, R. (2011). Foreign language teaching and educational policy. In K. Knapp \& B. Seidlhofer (Eds.), Handbook of foreign language communication and learning. Berlin \& New York: Walter de Gruyter.

Nesje Vestli, E. (2008). Fra sokkel til klasserom. Litteraturens plass $i$ fremmedspråkundervisningen (Fokus på språk, vol. 13). Halden: Fremmedspråksenteret.

Nussbaum, M. (2010). Not for Profit. Why democracy needs the Humanities. Princeton and Oxford: Princeton University Press.

O’Sullivan, E. \& Rösler, D. (2013). Kinder und Jugendliteratur im Fremdsprachenunterricht. Tübingen: Stauffenburg Verlag Brigitte Narr.

Olsbu, I. \& Salkjelsvik, K. (2008). Objetos perdidos: La literatura en clase de ELE. Europa y Noruega. Hispania 91(4), 865-876.

Olsen Eikrem, B. (1999). L97 and literature in TEFL: what the story has to offer: background thoughts, activities and teaching ideas. Kristiansand: Høyskoleforlaget.

Paran, A. (Ed.). (2006). Literature in Language Teaching and Learning. Alexandria, VA: TESOL.

Paran, A (2008). State - of - the - Art Article. The role of literature in instructed foreign language learning and teaching: An evidence based survey. Language Teaching, 41(4), 465-496.

Parkinson, B. \& Reid Thomas, H. (2000). Teaching Literature in a second language. Edinburgh: Edinburgh University Press.

Risager, K. (2003). Det nationale dilemma i sprog og kulturpcedagogikken. Roskilde: Akademisk.

Rosenblatt, L. M. (1994 [1978]). The reader, the text, the poem. The transactional theory of the literary work. Carbondale and Edwardsville: Southern Illinois University Press.

Scott, V. M. \& Tucker, H. (2001). SLA and the literature classroom: Fostering dialogues. Boston: Heinle \& Heinle.

Short, M. H. (1988). Reading, analyzing and teaching literature. London: Longman.

Simpson, P. (1997). Language through literature. London \& New York: Routledge.

Speller, J. (2011). Bourdieu and literature. Cambridge: Open Book Publishers.

Tornberg, U. (2013). What counts as "knowledge" in foreign language teaching and learning practices today? Foreign language pedagogy as a mirror of its time. Nordic Journal of Modern Language Methodology, 2(1), 1-12. Retrieved from http://journal.uia.no/index.php/NJMLM/article/view/77/63 
Trebbi, T. (2005). Det andre fremmedspråket: fra elitefag til et fag for alle? In K. Børhaug, A.-B. Fenner, \& L. Aase (Eds.), Fagenes begrunnelser. Skolens fag og arbeidsmåter $i$ danningsperspektiv (pp.103-112). Bergen: Fagbokforlaget.

Vaagland, E. (1991). I medgang og motgang. Skolefaget tysk fra 1869 til i dag. Trondheim: Tapir forlag.

Wales, K. (2011). A dictionary of stylistics. Harlow: Pearson.

Watson, G. \& Zyngier, S. (2007). Literature and stylistics for language learners. Theory and practice. New York: Palgrave Macmillan.

Widdowson, H.G. (1975). Stylistics and the teaching of literature. Harlow: Longman.

Widdowson, H.G. (1992). Practical stylistics. Oxford: Oxford University Press.

Wiland, S.M. (2007). Poetry: prima vista: reader response research in a foreign language context (Doctoral dissertation). Bergen: University of Bergen.

Williams, R. ([1976]1983). Keywords. A vocabulary of culture and society. London: Fontana Press.

Winther Jørgensen, M. \& Phillips, L. (2011). Diskursanalyse som teori og metode. Fredriksberg: Roskilde Universitetsforlag.

Aase, L. (2005). Skolefagenes ulike formål - danning og nytte. In K. Børhaug, A.-B. Fenner, \& L. Aase (Eds.), Fagenes begrunnelser. Skolens fag og arbeidsmåter $i$ danningsperspektiv (pp.15-27). Bergen: Fagbokforlaget.

Aasen, P. (2007). Læringsplakatens utdanningspolitiske kontekst. In J. Møller \& L. Sundli (Eds.), Lœringsplakaten. Skolens samfunnskontrakt. Kristiansand: Høyskoleforlaget.

\footnotetext{
${ }^{1}$ By L3 I mean the third language to be studied in the Norwegian school-system, Norwegian being the first language and English the second. The L3 is normally either German, French or Spanish, though some schools offer other alternatives. Since this terminology is specific to Norway, most of the research I refer to does not consider the distinction between L2 and L3. I will therefore also use the more wide-ranging concept of foreign languages (FL). The particular case of the L3 classroom in Norway is intrinsically related to general approaches to literature in FL teaching and learning as well as to macro-perspectives on education. As a consequence, this article combines a general perspective with a specific one, with special attention to the case of Norway.

${ }^{2}$ I use L3 to be consequent to the terminology in this article. The official English term is: Subject curriculum for foreign languages.

${ }^{3}$ The National Curriculum for Knowledge Promotion in Primary and Secondary Education.

${ }^{4}$ Informationszentrum für Fremdsprachenforschung der Phillips Universität, IFS.

${ }^{5}$ TodoEle.net is a web portal for teachers of Spanish as a FL. It includes both didactic and theoretical articles on the use of literary texts in the FL classroom.

${ }^{6}$ It should be stressed though, that not all scholars advocating a task-based approach would agree on this point

${ }^{7}$ Stylistics was originally informed by formalist and structuralist views on literature and language, but few would today understand literary language use as essentially different from language use in general.

${ }^{8}$ Bruner operates with the dichotomy of narrative mode of thought and paradigmatic mode of thought, exemplified, in its most prototypical expressions, by literary storytelling and the logical language of mathematics. The paradigmatic mode is monosignificative; it attempts to fix meaning and it is concerned with causality and general laws. The narrative mode is plurisignificative; it attempts to expand and open up for multiple meanings, it is concerned with human intentions and the possibility of other "worlds" (ways of thinking and living).

${ }^{9}$ For a comparison of their views, see Gonçalves Matos, 2012, pp. 87 - 104.

${ }^{10}$ Culture as the way people live their everyday lives. See also Kramsch, 2006, p. 13.

${ }^{11}$ Since it is difficult, as the authors recognize, to precisely quantify literariness, their examples of literary fiction are based on expert's judgments (i.e. literary jurors of prestigious literary awards) whereas the examples of popular fiction are taken from best-seller lists.

${ }^{12}$ Eagleton mentions five basic attributes that have been associated with literary texts: they can be fictional, convey insight in human existence, use language in a creative way, have no practical function, be appreciated as an especially valuable use of language. Some literary texts will have all these traits, while others only one or two.
} 